389

LONGITUDINAL STUDY OF TESTICULAR VOLUME DURING EARLY INFANCY. Fernando G. Cassorla, Stephen M. Golden, William M. Heroman, Roger E. Johnsonbaugh, D. Lynn Loriaux and Richard J. Sherins. $\overline{\mathrm{DEB}}$, NICHD, NIH and Nationa1 Nava1 Medical Center, Bethesda, Maryland 20014.

In an attempt to correlate possible changes in testicular volume with the rise in gonadotropins and testosterone which occurs during early infancy, we followed the testicular volume of 10 normal infants during the first 5 months of life. Using a calibrated orchidometer with reference beads of $0.5,1.0,1.5$, $2.0,2.5$, and $3.0 \mathrm{ml}$, a single observer performed testicular measurements at birth and at monthly intervals thereafter. Infants with hydrocele or undescended testes were excluded from the study. The mean testicular volumes for each side are shown in the following Table:

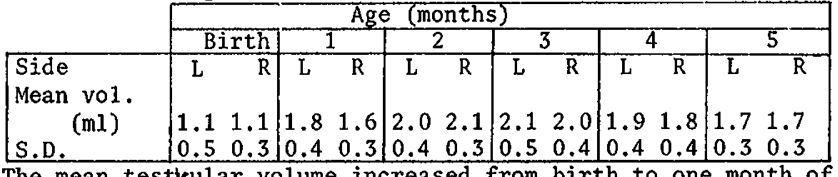

The mean testieular volume increased from birth to one month of age, reaching a peak at 2 to 3 months and decreased thereafter. Mean testicular volume at 1 month of age was significantly higher than at birth $(p<0.0025)$, and at 5 months significantly lower than at 2 months of age $(p<0.05)$. We conclude that changes in testicular volume closely parallel the known rise in gonadotropins and testosterone which occurs during early infancy.

\section{HORMONAL-METAL ION INTERACTION IN TESTICULAR}

FEMINIZATION. Wai-Yee Chan, Kyung W. Chung, Jim Bates, LeAnn Blomberg and Owen M. Rennert. University of Oklahoma Health Sciences Center, Department of Pediatrics, Biochemistry and Molecular Biology and Anatomical Sciences, Oklahoma City, Okahoma.

Testicular feminization syndrome, an X-linked recessive disorder in humans, is caused by the insensitivity of target organs such as testes to the stimulation of androgens. Two animal models are available, the tfm mouse and the $\mathrm{tfm}$ rat. In tfm rats abnormal androgen receptor binding and/or defective processing of testosterone occurs. Zinc has been reported to affect dihydrotestosterone-receptor binding in vitro. Our study reports an abnormal testicular zinc level in tfm rats. Copper and zinc concentrations in liver, kidney, adrenals, testes and plasma from tf $\mathrm{m}$ and control pairs were determined. Metal contents of the various tissues and plasma of $\mathrm{tfm}$ and normal control rats were comparable except testicular zinc which is lower in tfm testes.

\begin{tabular}{|c|c|c|c|}
\hline t & $\begin{array}{l}\text { Normal Testes } \\
29.89 \pm 4.65 \\
0.207 \pm 0.029 \\
0.481 \pm 0.079 \\
19.43 \pm 2.66\end{array}$ & $\begin{array}{l}\text { tfm Testes } \\
17.16 \pm 4.56 \\
0.126 \pm 0.034 \\
0.291 \pm 0.117 \\
7.85+2.97\end{array}$ & $\begin{array}{l}\text { Difference } \\
\text { s.d. }>99 \% \\
\text { s.d. }>99 \% \\
\text { s.d. }>99 \% \\
\text { s.d. }>99 \%\end{array}$ \\
\hline
\end{tabular}

Testicular zinc content is primarily under the influence of luteinizing hormone (LH) whose concentration is higher in tfm rats. The present results support the proposed metal carrier role of steroid-receptor complex and suggest the LH effect on zinc metabolism may be mediated through this complex. These data also suggest that the action of zinc and androgens on normal testicular development is interrelated.

391 TRIOL $\left(1,25 \mathrm{H}_{2}\right.$ D) RATIO: A MEANS OF EVALUATING CALCITRIOL SYNTHESIS IN DISORDERS OF CAICIUM METABOLISM. Russe11 W. Chesney, Alan Hamstra, Hector Deluca. University of Wisconsin, Departments of Pediatrics and Biochemistry, Madison WI. The clrculating level of calcitriol is of ten considered abnormal without regard to the factors responsible for calcitriol synthesis: serum $\mathrm{Ca}, \mathrm{PO}_{4}$ and $1 \mathrm{PTH}$ level. Using a precise assay for calcitriol and an antibody assay for C-terminal and intact PTH, a ratio of $\mathrm{PTH}$ to calcitriol was determined in several disorders.

\begin{tabular}{|c|c|c|c|c|}
\hline GROUP & $\mathrm{Ca}(\mathrm{mg} / \mathrm{dl})$ & $\mathrm{PO}_{4}(\mathrm{mg} / \mathrm{dl})$ & $\mathrm{PTH} / 1,25-\mathrm{D}$ & $\mathrm{N}$ \\
\hline Control & $\overline{9.5 \pm 0.1(S E)}$ & $3.9+0.1$ & $0.74+.13$ & $\overrightarrow{14}$ \\
\hline Mild renal Dx & $9.5 \mp 0.1$ & $3.9 \mp 0.1$ & $0.26 \bar{\mp} .06$ & 6 \\
\hline Moderate renal Dx & $9.7 \mp 0.1$ & $4.7+0.5$ & $6.47 \bar{\mp} 1.1 *$ & 8 \\
\hline Severe renal Dx & $8.5 \pm 0.4 *$ & $5.5 \pm 0.4 *$ & $75.4+\overline{2} 8.7 *$ & 13 \\
\hline Renal Dx \& 1,25 Dx & $10 . \overline{0}+0.1$ & $4.8+0.2 *$ & $8.4+1.3 *$ & 24 \\
\hline Hypoparathyroid & $7.4+0.2 *$ & $7.2 \mp 0.6^{*}$ & $0.1 \overline{5}+.15 *$ & 6 \\
\hline Hypophos rickets & $9.5 \mp 0.1$ & $3.0+0.1 *$ & $2.70 \overline{+0} .6 *$ & 11 \\
\hline 250H-D deficiency & $8.4 \mp 0.2 *$ & $1.6+0.4 *$ & $3.03+1.0 *$ & 4 \\
\hline
\end{tabular}

(*p $<.01$ from controls). Normal PTH is $20-70 \mathrm{ul} \overline{\mathrm{E} q} / \mathrm{ml}$ and normal calcitriol is $43 \pm 2 \mathrm{pg} / \mathrm{m} 1$

These data suggest decreased calcitriol synthesis in moderate and severe renal failure, hypophosphatemic rickets with vitamin $\mathrm{D}_{2}$ and 250H-D deficiency despite high $\mathrm{PTH} / \mathrm{calcitriol}$ ratios. Hypoparathyroid subjects have a lower ratio. This ratio demonstrated the influence of calcitriol $R x$ in patients with renal fallure. This ratio may prove useful in evaluating the vitamin $D$ status of a patient, the response to therapy and a better understanding of pathogenic mechanisms.
392 THE CIRCULATING LEVELS OF VITAMIN D METABOLITES IN TRIOL $\left(1,25 \mathrm{H}_{2}\right.$-VITAMIN D) LEVELS. Russell W. Chesney, Jerry Zimmexman, Alan Hamstra, Hector DeLuca. University of Wisconsin Medical School, Clinical Science Center, Departments of Pediatrics and Blochemistry, Madison, Wisconsin.

Using a specific vitamin D metabolite assay, the serum levels of vartous metabolites were measured in 3 children with a history of decreased dietary intake of vitamin $D$ and sun exposure; two had rickets, aminoacidurla and elevated IPTH levels. In some osteomalacic adults, calcitriol levels are sald to be normal (Eastwood et al, Lancet 1:1377, 1979; Rasmussen, Am J Med 69:360,1980).

\begin{tabular}{ccccccc}
\hline PATIENT & $\begin{array}{c}\mathrm{Ca} \\
(\mathrm{mg} / \mathrm{d} 1)\end{array}$ & $\begin{array}{c}\mathrm{PO}_{4} \\
(\mathrm{mg} / \mathrm{d} 1)\end{array}$ & $\begin{array}{c}250 \mathrm{H}-\mathrm{D} \\
(\mathrm{ng} / \mathrm{dl})\end{array}$ & $\begin{array}{c}24,25 \mathrm{HH}_{2} \mathrm{D} \\
(\mathrm{ng} / \mathrm{d} 1)\end{array}$ & $\begin{array}{c}\mathrm{Ca} 1 \mathrm{cl}- \\
\text { triol }\end{array}$ & $\begin{array}{c}\text { IPTH } \\
(\mathrm{u} 1 \mathrm{Eq} / \mathrm{ml})\end{array}$ \\
\hline 1 & 8.6 & 2.6 & 9.3 & Not found & 52 & 98 \\
2 & 7.9 & 0.8 & 7.0 & Not found & 47 & 82 \\
3 & 8.4 & 1.6 & 5.6 & Not found & 50 & 120 \\
norma1 & $9.4-10.2$ & $3.5-5$ & $34+5(\mathrm{SD})$ & $1.71+0.5$ & $43+12$ & $20-70$ \\
\hline
\end{tabular}

Despite reduced 250H-D levels, calcitriol levels are in the normal range. Nonetheless, the combination of hypocalcemia, hypophosphatemia and increased IPTH should result in even higher calcitriol levels. The ratio of PTH/calcltriol is signiftcantly higher in these patients with reduced $250 \mathrm{H}-\mathrm{D}$ levels 2.00 vs. 1.06 suggesting actually reduced synthesis of calcitriol in these patients. Non-detection of $24,25 \mathrm{OH}_{2} \mathrm{D}$ can be explained by high iPTH and low $\mathrm{PO}_{4}$ levels rather than reflecting the inability to synthesize this metabolite. The evaluation of vitamin D deficiency should Include the measurement of all metabolites.

THE NATURE OF HYPOTHYROXINEMIA IN SICK PRETERM INFANTS.

393 Parveen Chowdhry, Richard Auerbach, John Scanlon and

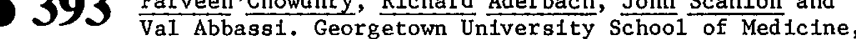
Department of Pediatrics, Washington, D.C. 20007.

To evaluate the nature of hypothyroxinemia in small sick preterm infants, the hypothalamic-pituitary-thyroid axis was evaluated by determining the thyrotropin-response to TRH. Preterm infants of gestational ages $26-28$ weeks, with $\mathrm{T}_{4}<4 \mu \mathrm{g} / \mathrm{dl}$ on two occasions and low TSH $(<20 \mu u / m 1)$ were Included in a double blind study. Following a TRH test, $20 \mu \mathrm{g} / \mathrm{kg}$ IV babies were assigned to a therapeutic regimen of either $\mathrm{T} 4(10 \mathrm{\mu g} / \mathrm{kg})$ or placebo. Nine bables were tested prior to therapy, 3 from T4 group and 6 from placebo group. Four bables, 2 from each group were tested 1-2 wks post therapy and 4 were not tested. In untreated babies the baseline TSH of $7.25+1.4$ rose to $23.7+4.1 \mu \mathrm{u} / \mathrm{ml}$ at $30^{\prime}$. This response was slightly, but not significantly greater than that in full term babies, $23.7 \pm 4.1$ vs $16.6+0.97, \mathrm{P}>0.05$. In 2 babies treated with T4, TSH response was completely suppressed. Serial $\mathrm{T} 4$ assay showed normalization of T4 in both groups at about the same time interval, $22.9+4.1$ vs $23.8+$ 4.9 days, $P>0.5$. There was no beneficial effect of $\bar{T} \overline{4}$ therapy on head growth $23.0 \pm 0.5$ vs $31.2+0.6 \mathrm{~cm}, \mathrm{P}>0.05$, length $42.5 \pm 0.6$ vs $42.0 \pm 0.7 \mathrm{~cm}, P>0 . \overline{05}$, weight $1 \overline{9} 87 \pm 100$ vs $1951 \pm 105 \mathrm{gms}$, $P>0 . \overline{0}$, or duration of hospitalization $98 . \overline{8}+8.5$ vs $110 \overline{+8} .3$ day, $\mathrm{P}>0.05$.

In conclusion: hypothroxinemia in sick preterm infants is not caused by hypothyroidism. The physiological pituitary responses to stimulatory effect of TRH and suppressive action of T4 negate such a posstbility. Based on these observations routine supplemental T4 therapy in preterm infants with low T4 is unwarranted.

\begin{abstract}
394 T. 394 Robert M. Ehrlich). Hosp. S1ck Ch11d., Dept. Peds.Tor. Hyperthyroidism is most commonly seen in Grave's disease, Hashimoto's thyrolditis, or following inflammation of the thyroid. We have identified a patient in whom transient hyperthyroldism presented during the acute phase of an Hydralazine-1nduced lupus erythematous (LE) syndrome. This association has not been previously described. A 15 year old female with pyelonephritis and hypertension on Hydralazine, Propranolol and diuretics presented with a one month history of 20 lbs welght 10ss, amenorrhea and polyarthralgla. On physical examination: HR $110 / \mathrm{m} 1 \mathrm{n}$, non-tender, symmetric goltre ( $3 X \mathrm{~N})$, and synovitis of wrists and knees. On Investigation: ESR 103, LE Prep posttive, DNA binding positive, ANF $>1: 1280$, and complement levels normal. Serum T4 was $17 \mu \mathrm{gm} /$ d1 (N 4-12), total T3 $160 \mathrm{ng} / \mathrm{d} 1$ (N $90-220$ ), T3 resin uptake $37 \%$ (N 25-35), TSH $<1 \mu \mathrm{U} / \mathrm{ml}(\mathrm{N}<10)$. I I 131 uptake was depressed: 2 hrs, $2.1 \%$ (N 3-9); $24 \mathrm{hrg}, 4.9 \%$ (N 5-25). The patient's serum was negative for thyroid stimulating 1mmunoglobulin (TSI), ant1thyroglobulin and anti-microsomal antibodies. Off Hydralazine, the synovitis rapidiy resolved and three months later without anti-thyrold therapy, she appeared completely normal with regain in her weight and reappearance of menses. Her T4 was $5.8 \mu \mathrm{gm} / \mathrm{dl}$, TSH $4.2 \mu \mathrm{U} / \mathrm{ml}$. The parallel courses of the LE syndrome and the hyper thyro1dism Imply a common et lology. Depression of $I^{131}$ uptake and absence of TSI suggest an inflammatory process, while absence of specific thyrold antibodies make Hashimoto's disease unlikely. We conclude that hyperthyroldism may be a feature of
the LE syndrome caused by Hydralazine.
\end{abstract}

